\title{
Organosulfates in Atlanta, Georgia: anthropogenic influences on biogenic secondary organic aerosol formation
}

\author{
Anusha Priyadarshani Silva Hettiyadura ${ }^{1}$, Ibrahim M. Al-Naiema ${ }^{1}$, Dagen D. Hughes ${ }^{1}$, Ting Fang ${ }^{2, a}$, and \\ Elizabeth A. Stone ${ }^{1}$ \\ ${ }^{1}$ Department of Chemistry, University of Iowa, Iowa City, IA 52242, USA \\ ${ }^{2}$ School of Earth and Atmospheric Sciences, Georgia Institute of Technology, Atlanta, GA 30332, USA \\ anow at: University of California, Irvine, Irvine, CA 92697, USA
}

Correspondence: Elizabeth A. Stone (betsy-stone@uiowa.edu)

Received: 10 August 2018 - Discussion started: 26 September 2018

Revised: 18 January 2019 - Accepted: 30 January 2019 - Published: 12 March 2019

\begin{abstract}
Organosulfates are secondary organic aerosol (SOA) products that form from reactions of volatile organic compounds (VOC), such as isoprene, in the presence of sulfate that is primarily emitted by fossil fuel combustion. This study examines the anthropogenic influence on biogenic organosulfate formation at an urban site in Atlanta, Georgia (GA) in the southeastern United States (US). Organosulfates were analyzed in fine particulate matter $\left(\mathrm{PM}_{2.5}\right)$ collected during August 2015 in Atlanta using hydrophilic interaction liquid chromatography (HILIC), tandem mass spectrometry (MS/MS), and high-resolution time-of-flight (ToF) mass spectrometry. By their MS/MS response, 32 major organosulfate species were identified, selected species were quantified, and other species were semi-quantified using surrogate standards. Organosulfates accounted for $16.5 \%$ of $\mathrm{PM}_{2.5}$ organic carbon (OC). Isoprene-derived organosulfates were the most abundant, dominated by methyltetrol sulfate which accounted for $12.6 \%$ of $\mathrm{PM}_{2.5}$ OC. Together, the isoprene-derived organosulfates accounted for the majority of the isoprene-derived SOA that had been previously observed in Atlanta, but had not been identified at the molecular level. Other major species included seven monoterpenederived organosulfates, five diesel and/or biodiesel-derived organosulfates, and three new organosulfates that are also expected to derive from isoprene. Organosulfate species and concentrations in Atlanta were compared to those in a rural forested site in Centreville, Alabama (AL) during summer 2013, which were also dominated by isoprene-derived organosulfates. In Atlanta, isoprene-derived organosulfate concentrations were 2-6 times higher and accounted for
\end{abstract}

twice as much OC. The greatest enhancement in concentration was observed for 2-methylglyceric acid sulfate whose formation is enhanced in the presence of nitrogen oxides (NO and $\mathrm{NO}_{2} ; \mathrm{NO}_{x}$ ) and is a tracer for isoprene high-NO $\mathrm{NO}_{x} \mathrm{SOA}$. The isoprene-derived organosulfates indicated a stronger influence of $\mathrm{NO}_{x}$ in Atlanta compared to Centreville. Overall, these results suggest that SOA in the southeastern US can be reduced by controlling $\mathrm{NO}_{x}$ and $\mathrm{SO}_{2}$ emissions from fossil fuel combustion. This study gives insights into the major organosulfate species that should be targets for future measurements in urban environments and standard development.

\section{Introduction}

Organosulfates are components of atmospheric secondary organic aerosol (SOA) that contain a sulfate ester functional group. This class of compounds has been detected in ambient aerosols around the world, including rural, urban, forested, and coastal sites in the United States (US), China, and/or Europe (Hansen et al., 2014; He et al., 2014; Kristensen and Glasius, 2011; Lin et al., 2012; Stone et al., 2012; Ma et al., 2014). In the southeastern US, organosulfates are estimated to contribute up to between $5 \%$ and $9 \%$ of $\mathrm{PM}_{2.5}$ (fine particulate matter with aerodynamic diameter less than $2.5 \mu \mathrm{m}$ ) organic aerosol (OA) (Tolocka and Turpin, 2012). Organosulfates primarily form by the reactive uptake of gasphase epoxides on acidic sulfate particles (Surratt et al., 2010; Lin et al., 2013). Alternatively, they form by reaction of oxidized volatile organic compounds (VOC) with sul- 
fate radicals (Nozière et al., 2010; Schindelka et al., 2013) and nucleophilic substitution of nitrate groups by sulfate (Darer et al., 2011; Hu et al., 2011). Biogenic VOC precursors of organosulfates include isoprene, monoterpenes, sesquiterpenes, 2-methyl-3-butene-2-ol (MBO), and green leaf volatiles (Zhang et al., 2012; Surratt et al., 2008; Chan et al., 2011; Iinuma et al., 2009; Shalamzari et al., 2014). As fossil fuel combustion is the major source of sulfate aerosols in the atmosphere (Wuebbles and Jain, 2001; Hidy et al., 2014; Carlton et al., 2010), biogenic VOC derived organosulfates are useful as tracers of anthropogenically influenced biogenic SOA (Hettiyadura et al., 2018). Organosulfates have also been detected among the SOA generated from diesel and biodiesel fuel emissions (Blair et al., 2017) and in SOA produced from aromatic VOC such as naphthalene and methylnaphthalene (Riva et al., 2015) as well as long chain $n$-alkanes (Riva et al., 2016b).

Atlanta, Georgia (GA) is the principle city of the Atlanta metropolitan area (Atlanta-Sandy Springs-Roswell, GA), which is the ninth most populous metropolitan area in the US as of 2017 with a population of 5.9 million (U.S. Census Bureau, 2018). Here, OA accounts for $68 \%-70 \%$ of $\mathrm{PM}_{1}$ (fine particulate matter with aerodynamic diameter less than $1 \mu \mathrm{m}$ ) mass (Rattanavaraha et al., 2017) and $71 \%$ of $\mathrm{PM}_{2.5}$ mass during summer (Al-Naiema et al., 2019), the majority of which is secondary in origin and mainly derived from biogenic VOC (Weber et al., 2007). For example, isoprene dihydroxy epoxides (IEPOX) contributed $29 \%-38 \%$ of $\mathrm{PM}_{1}$ OA (Rattanavaraha et al., 2017; Budisulistiorini et al., 2016; $\mathrm{Xu}$ et al., 2015a) and total isoprene-derived OA contributed to $27 \%$ of $\mathrm{PM}_{2.5}$ organic carbon (OC) (Al-Naiema et al., 2019). The diurnal variation of isoprene-derived OA in urban Atlanta, GA, was temporally consistent with isoprene emissions from plants, suggesting that isoprene-derived OA forms locally rather than being transported from surrounding forested sites (Xu et al., 2015b). In Atlanta, sulfate is the second largest component of fine PM and accounts for $15 \%$ of $\mathrm{PM}_{2.5}$ (Al-Naiema et al., 2019) and $17 \%-21 \%$ of $\mathrm{PM}_{1}$ mass (Rattanavaraha et al., 2017). The aerosol acidity (average $\mathrm{pH} 1.4 \pm 0.7$ ) and aerosol water content (averaging $8.4 \pm 4.8 \mu \mathrm{g} \mathrm{m}^{-3}$ ) in Atlanta also peak during summer (Rattanavaraha et al., 2017), similar to other locations in the southeastern US (Guo et al., 2015). In addition, previous studies have demonstrated that the biogenic SOA formation in the southeastern US is enhanced by sulfate, $\mathrm{NO}_{x}$, and $\mathrm{O}_{3}$, which mainly come from fossil fuel combustion, particularly during summer when the biogenic emissions are high (Goldstein et al., 2009; Gao et al., 2006; Xu et al., 2015a; Carlton et al., 2010).

This study examines the anthropogenic influence on organosulfate formation during summer at an urban site in Atlanta in the southeastern US. Our specific objectives include the following: (1) identification and quantification of major organosulfate species in Atlanta, GA, during August 2015 using hydrophilic interaction liquid chromatog- raphy (HILIC), tandem mass spectrometry (MS/MS), and high-resolution time-of-flight mass spectrometry (ToF-MS); (2) evaluation of the factors that influence organosulfate formation via comparison of observed species with SOA chamber experiments and correlations of organosulfates with SOA tracers, other $\mathrm{PM}_{2.5}$ constituents, gas-phase reactive species, and meteorological conditions; and (3) comparison of these results with the major organosulfates identified and quantified in Centreville, Alabama (AL) during summer 2013 (Hettiyadura et al., 2017, 2018) to better understand the extent to which anthropogenic pollutants affect biogenic organosulfate formation across an urban and rural pair in the southeastern US during summer. This study provides insights into the composition, abundance, sources, and formation pathways of organosulfates, which are useful as tracers for anthropogenically influenced SOA.

\section{Materials and methods}

\subsection{Chemicals and reagents}

Hydroxyacetone sulfate and glycolic acid sulfate (potassium salts, $>95 \%$ purity) were synthesized according to Hettiyadura et al. (2015); lactic acid sulfate ( $24.9 \%$ purity) was synthesized according to Olson et al. (2011); methyltetrol sulfates was synthesized according to Budisulistiorini et al. (2015) and Bondy et al. (2018). Ultra-pure water was prepared on site (Thermo, Barnsted Easypure-II; $18.2 \mathrm{M} \Omega \mathrm{cm}^{-1}$ resistivity, with total organic carbon (OC) $\left.<40 \mu \mathrm{gL}^{-1}\right)$. Other reagents include acetonitrile $\left(\right.$ Optima $^{\mathrm{TM}}$, Fisher Scientific), ammonium acetate ( $\geq 99 \%$, Fluka, Sigma Aldrich), and ammonium hydroxide (Optima, Fisher Scientific).

\section{$2.2 \quad \mathbf{P M}_{2.5}$ sample collection}

$\mathrm{PM}_{2.5}$ samples were collected in Atlanta, GA, from 29 July to 27 August 2015. A medium volume sampler (3000B, URG Corp.) operating at a flow rate of $90 \mathrm{Lmin}^{-1}$ was used to collect $\mathrm{PM}_{2.5}$ on pre-baked $\left(550^{\circ} \mathrm{C}\right.$ for $\left.18 \mathrm{~h}\right)$ quartz-fiber filters $\left(90 \mathrm{~mm}\right.$, Pallflex ${ }^{\circledR}$ Tissuquartz ${ }^{\mathrm{TM}}$, Pall life science). The $\mathrm{PM}_{2.5}$ sampler was placed on the roof top of the School of Earth and Atmospheric Sciences building at the Georgia Institute of Technology $\left(33^{\circ} 46^{\prime} 44.2^{\prime \prime} \mathrm{N}, 84^{\circ} 23^{\prime} 46.2^{\prime \prime} \mathrm{W}\right.$; height $\sim 30-40 \mathrm{~m}$ ). A detailed description of the sampling site is provided by Verma et al. (2014). Samples were collected daily from 13:30 to 12:30 the next day (local time). One filter blank was collected for every five $\mathbf{P M}_{2.5}$ samples. Samples from 29 July, 3, 11, and 19 August were not analyzed for organosulfates, as the filters were used for a different purpose. The collected samples were placed in aluminium-lined (pre-baked at $550^{\circ} \mathrm{C}$ for $18 \mathrm{~h}$ ) petri dishes, sealed with Teflon tape, and stored at $-20^{\circ} \mathrm{C}$ until extracted. 


\subsection{Extraction of organosulfates}

Organosulfates were extracted according to the method described in Hettiyadura et al. (2015) that has been demonstrated to efficiently recover $83 \%-121 \%$ of organosulfates with aliphatic, aromatic, carbonyl, hydroxyl, and carboxyl acid groups. Briefly, subsamples of filters (averaging $\sim 3 \mathrm{~cm}^{2}$ ) were extracted with $10.0 \mathrm{~mL}$ of acetonitrile and ultra-pure water ( $95: 5$, by volume) for $20 \mathrm{~min}$ by ultrasonication (5510, Branson). The sample extracts were filtered using polypropylene membrane syringe filter discs $\left(0.45 \mu \mathrm{m}\right.$ pore size, Puradisc ${ }^{\mathrm{TM}} 25 \mathrm{PP}$, Whatman $\left.{ }^{\circledR}\right)$. The extracts were evaporated to dryness under ultra-high purity nitrogen gas at $50{ }^{\circ} \mathrm{C}$ (Turbovap ${ }^{\circledR} \mathrm{LV}$, Caliper Life Sciences, Reacti-Therm III TS 18824, and Reacti-Vap I 18825, Thermo Scientific). Dried extracts were reconstituted in $600 \mu \mathrm{L}$ of acetonitrile and ultra-pure water ( $95: 5$ by volume).

\subsection{Quantification of organosulfates}

Organosulfates were quantified using HILIC and tandem mass spectrometry (MS/MS) in negative (-) ion mode, using an ultra-performance liquid chromatography system (UPLC, ACQUITY UPLC H-Class, Waters) coupled with a triple quadrupole (TQ) mass spectrometer (AQCUITY, Waters) and an electrospray ionization (ESI) source. The separation of organosulfates was performed on an ethylene-bridged hybrid amide column using an acetonitrile-rich mobile phase (acetonitrile and ultra-pure water; $95: 5$ ) and an aqueous mobile phase (ultra-pure water; $100 \%$ ). Both mobile phases were buffered at $\mathrm{pH} 9$ with $10 \mathrm{mM}$ ammonium acetate and ammonium hydroxide. Organosulfates were eluted using a stepwise gradient as described in Hettiyadura et al. (2015). Briefly, the acetonitrile-rich mobile phase was held at $100 \%$ from 0 to $2 \mathrm{~min}$, and then decreased to $85 \%$ from 2 to $4 \mathrm{~min}$ and held constant at $85 \%$ until $11 \mathrm{~min}$. Targeted analysis was performed in multiple reaction monitoring mode. Hydroxyacetone sulfate and glycolic acid sulfate were quantified using authentic standards. Lactic acid sulfate and methyltetrol sulfate were quantified using their response factors determined previously using authentic standards. Notably, these prior experiments had response factors (determined as the slope of the calibration curve) for glycolic acid sulfate and hydroxyacetone sulfate that were within $10 \%$ of the current experiments, indicating that instrument performance and ionization were consistent within $10 \%$. The optimized ESI(-)MS/MS conditions used for each of these organosulfates are given in Hettiyadura et al. (2015, 2018), respectively.

Semi-quantitation of other organosulfates was based upon the MS/MS response of authentic standards and matched to the sulfur-containing fragment ions observed. For semiquantitation of organosulfates that fragmented to the bisulfate anion $(m / z 97$, Fig. 1a), one of three surrogate standards were used: for $m / z 211,213$, and 260 the response factor of methyltetrol sulfate was used; for other organosulfates elut- ing prior to 4 min hydroxyacetone sulfate was used, and for those retaining more than 4 min glycolic acid sulfate was used. For the semi-quantitation of organosulfates that fragmented only to the sulfate radical anion $(m / z 96$, Fig. $1 b)$, methyl sulfate was used. For organosulfates with $m / z$ 137, 139 , and 296 that fragmented to the sulfite radical anion $(m / z$ 80, Fig. 1d) hydroxyacetone sulfate was used. The cone voltage and collision energy used for the organosulfates that were semi-quantified using surrogate standards were the same as the ESI(-)-MS conditions used for corresponding precursor ion scans (given in Sect. 2.5.1). The uncertainty of the organosulfate concentrations was calculated accounting for relative errors in air volume, extraction efficiency, and instrumental analysis according to the method described in Hettiyadura et al. (2017). The relative error in the instrument analysis was propagated using the limit of detection and the relative standard deviation for each organosulfate standard given in Hettiyadura et al. (2015). For methyltetrol sulfate and the other organosulfates that did not have authentic standards, the analytical uncertainty was estimated as $30 \%$ of their concentration values (Hettiyadura et al., 2018). This uncertainty does not account for any bias introduced by the use of a surrogate standard, which can only be evaluated by using an authentic standard. All data were acquired and analyzed using MassLynx and QuanLynx softwares (Waters Inc., version 4.1).

\subsection{Qualitative analysis of organosulfates}

\subsubsection{Precursor ion scans}

Sample analysis was performed on the UPLC-TQ in precursor ion mode as described in Hettiyadura et al. (2017). Briefly, a respective cone voltage and collision energy of $28 \mathrm{~V}$ and $16 \mathrm{eV}$ were used for the $\mathrm{m} / \mathrm{z} 97$ precursor ion scan, whereas a respective cone voltage and collision energy $42 \mathrm{~V}$ and $20 \mathrm{eV}$ were used for the $\mathrm{m} / \mathrm{z} 96$ precursor ion scan. In addition, precursor ion scans of $m / z 81$ (bisulfite anion) and $m / z 80$ were used to identify organosulfates that did not fragment into $m / z 97$ or 96 , for which a cone voltage of $34 \mathrm{~V}$ and a collision energy of $18 \mathrm{eV}$ were used. A mass range of 100$400 \mathrm{Da}$ was used in all precursor ion scans. The data were acquired and analyzed using MassLynx and QuanLynx software packages (Waters Inc., version 4.1).

\subsubsection{Chemical characterization and structure elucidation}

PM extracts were also analyzed by a UPLC-ToF mass spectrometer (Bruker Daltonics MicrOTOF) to determine the elemental composition and structural information of the major sulfur-containing species. The ESI(-) conditions included a capillary voltage of $2.6 \mathrm{kV}$, a cone voltage of $30 \mathrm{~V}$, and a desolvation gas flow rate of $600 \mathrm{Lh}^{-1}$. Other ESI(-)-MS conditions used were the same as in Hettiyadura et al. (2015). Data 


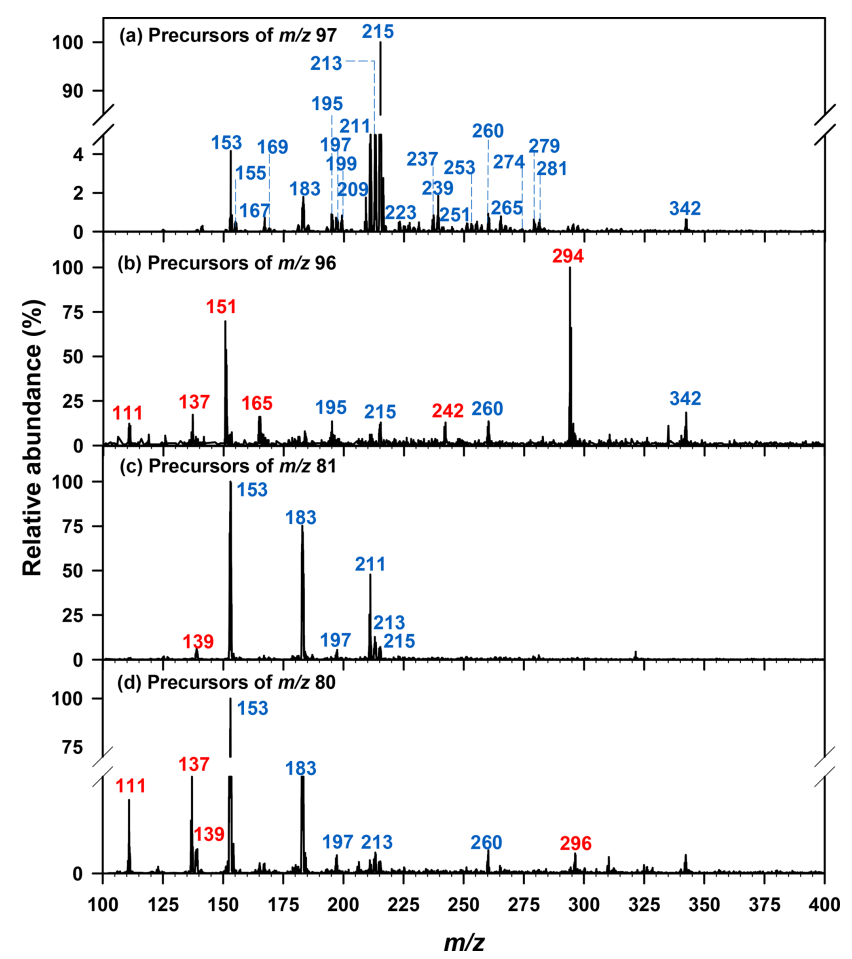

Figure 1. Precursors of (a) bisulfate ion $(\mathrm{m} / \mathrm{z}$ 97), (b) sulfate ion radical $(m / z, 96)$, (c) bisulfite ion $(m / z 81)$, and (d) sulfite ion radical $(m / z$ 80) identified from a sample collected on 30 July 2015 in Atlanta. Blue indicates nominal $\mathrm{m} / \mathrm{z}$ of the major organosulfate species that were identified from the precursor $\mathrm{m} / \mathrm{z}, 97$ scan. Red indicates nominal $\mathrm{m} / \mathrm{z}$ of the major organosulfate species that were identified from the precursor $m / z 96,81$, and 80 scans.

were collected in a mass range from 100 to $400 \mathrm{Da}$. A peptide, Val-Tyr-Val ( $m / z$ 378.2029, Sigma-Aldrich), was used as the lock mass to correct for any instrument drift. Molecular formulas were assigned considering both odd and even electron states, $\mathrm{C}_{1-25}, \mathrm{H}_{0-50}, \mathrm{O}_{3-20}, \mathrm{~S}_{1-2}, \mathrm{~N}_{0-5}$, and a maximum error of $10 \mathrm{mDa}$. The data were acquired and analyzed using MassLynx software (Waters Inc., version 4.1) and an elemental composition tool (Waters Inc., version 4.0).

\subsection{Collocated measurements}

Percent contributions of organosulfates to $\mathrm{PM}_{2.5} \mathrm{OC}$ were compared to determine the relative abundances of the major organosulfates in Atlanta and Centreville. OC in the $\mathrm{PM}_{2.5}$ samples was measured on $1 \mathrm{~cm}^{2}$ filter punches using a thermal-optical analyzer (Sunset laboratory) according to Schauer et al. (2003). Filter-based measurements of other $\mathrm{PM}_{2.5}$ components, gas-phase measurements, and meteorological conditions were used in correlation analysis to provide insight to precursors and formation pathways of organosulfates. Isoprene SOA tracers (2-methylthreitol, 2-methylerythritol, 2-methylglyceric acid, cis-2-methyl1,3,4-trihydroxy-1-butadiene, 3-methyl-2,3,4-trihydroxy- 1-butene, and trans-2-methyl-1,3,4-trihydroxy-1-butene), cis-pinonic acid, $\beta$-caryophyllinic acid, meso-erythritol, 2,3-dihydroxy-4-oxopentanoic acid, aromatic dicarboxylic acids (phthalic acid, terephthalic acid, isophthalic acid, and 4-methylphthalic acid), and mononitroaromatic compounds (4-nitrophenol, 2-methyl-4-nitrophenol, 4-methyl-2nitrophenol, 4-nitrocatechol, 3-methyl-6-nitrocatechol, and 3-methyl-5-nitrocatechol) were measured by gas chromatography (GC)-MS according to the methods described in Al-Naiema and Stone (2017). Sulfate was measured by ion chromatography following Jayarathne et al. (2014). The hourly based measurements of $\mathrm{O}_{3}, \mathrm{NO}_{x}$ (nitrogen oxides such as, $\mathrm{NO}$ and $\mathrm{NO}_{2}$ ), and solar radiation were obtained from the Southeastern Aerosol and Research Characterization network monitoring site at Jefferson Street (JST) located $2 \mathrm{~km}$ west of the sampling site and were averaged across the sample collection time. Detailed descriptions of their quantification methods are described in Hansen et al. (2003).

\subsection{Correlation analysis}

Pearson correlation coefficients were assessed using a statistical analysis software $\left(\mathrm{IBM}^{\circledR}\right.$ SPSS $^{\circledR}$ statistics, version 25$)$. Correlations were interpreted as very strong $(0.9-1.0)$, strong $(0.7-0.9)$, moderate $(0.5-0.7)$, weak $(0.3-0.5)$, or negligible $(0.0-0.3)$ (Hinkle et al., 2003). The correlations were considered as statistically significant at the $95 \%$ confidence level.

\section{Results and discussion}

\subsection{Quantitative analysis of organosulfates}

Quantitative information about the organosulfates observed in Atlanta is summarized in Table 1, with time series of selected species shown in Fig. 2. Methyltetrol sulfate is the most abundant quantified organosulfate, contributing $12.6 \%$ of $\mathrm{PM}_{2.5}$ OC, followed by $m / z 211$ (0.93\%), $213(0.80 \%)$, glycolic acid sulfate $(0.24 \%), 2$-methylglyceric acid sulfate $(0.32 \%)$, and lactic acid sulfate $(0.20 \%)$ (Table 2$)$. The remaining 26 organosulfates were estimated to contribute $1 \%$ of $\mathrm{PM}_{2.5}$ OC. Altogether, the 32 measured organosulfates in Table 1 account for $16.5 \%$ of $\mathrm{PM}_{2.5}$ OC. These results indicate that organosulfates in Atlanta during August 2015 were dominated by methyltetrol sulfate, with minor contributions from many other organosulfate species derived from isoprene, monoterpenes, and anthropogenic sources.

\subsection{Qualitative analysis of major organosulfates}

Organosulfates were identified by precursors to $\mathrm{m} / \mathrm{z} 97$ $\left(\mathrm{HSO}_{4}^{-}\right), 96\left(\mathrm{SO}_{4}^{-\bullet}\right), 81\left(\mathrm{HSO}_{3}^{-}\right)$, and $80\left(\mathrm{SO}_{3}^{-\bullet}\right)$ in three $\mathrm{PM}_{2.5}$ samples collected on 30-31 July and 1 August 2015. Results were similar for all three samples; therefore, the results obtained only for the 30 July sample are shown in Fig. 1. Major organosulfur compounds were defined in one of the 
Table 1. The major organosulfates identified using HILIC-TQ in daily $\mathrm{PM}_{2.5}$ samples collected from Atlanta, GA, in August 2015, indicating nominal mass-to-charge ratio $(\mathrm{m} / \mathrm{z}$ ), chemical formula, and monoisotopic mass determined from HILIC-ToF, proposed structure (with a star indicating many isomers, although only one is shown), potential VOC precursors, and their average ambient concentrations with one standard deviation (SD). For these organosulfates the median and the maximum error in the observed mass is 1.7 and $7.5 \mathrm{mDa}$, respectively. Organosulfates are ordered in the table from greatest to lowest abundance.

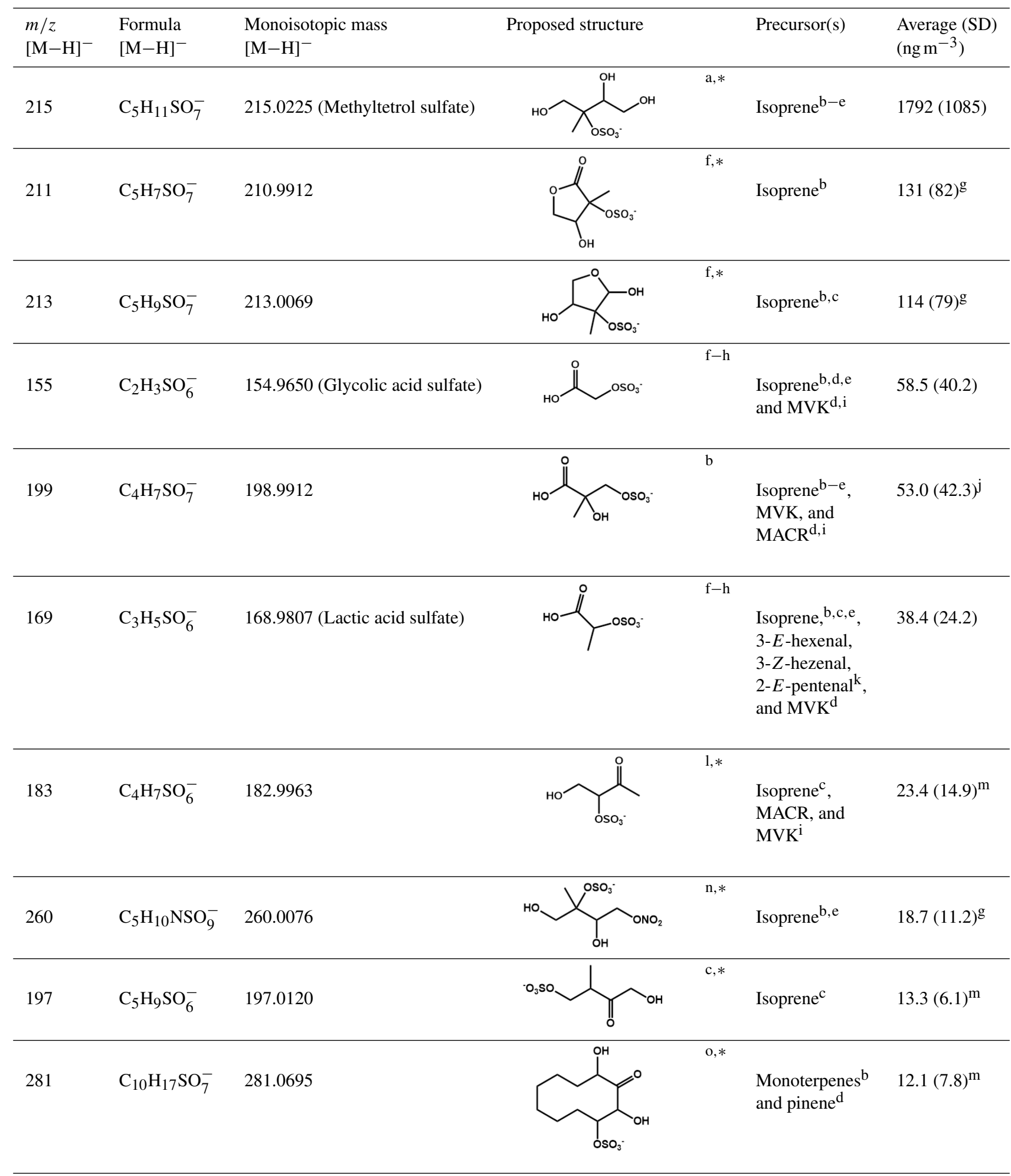


Table 1. Continued.

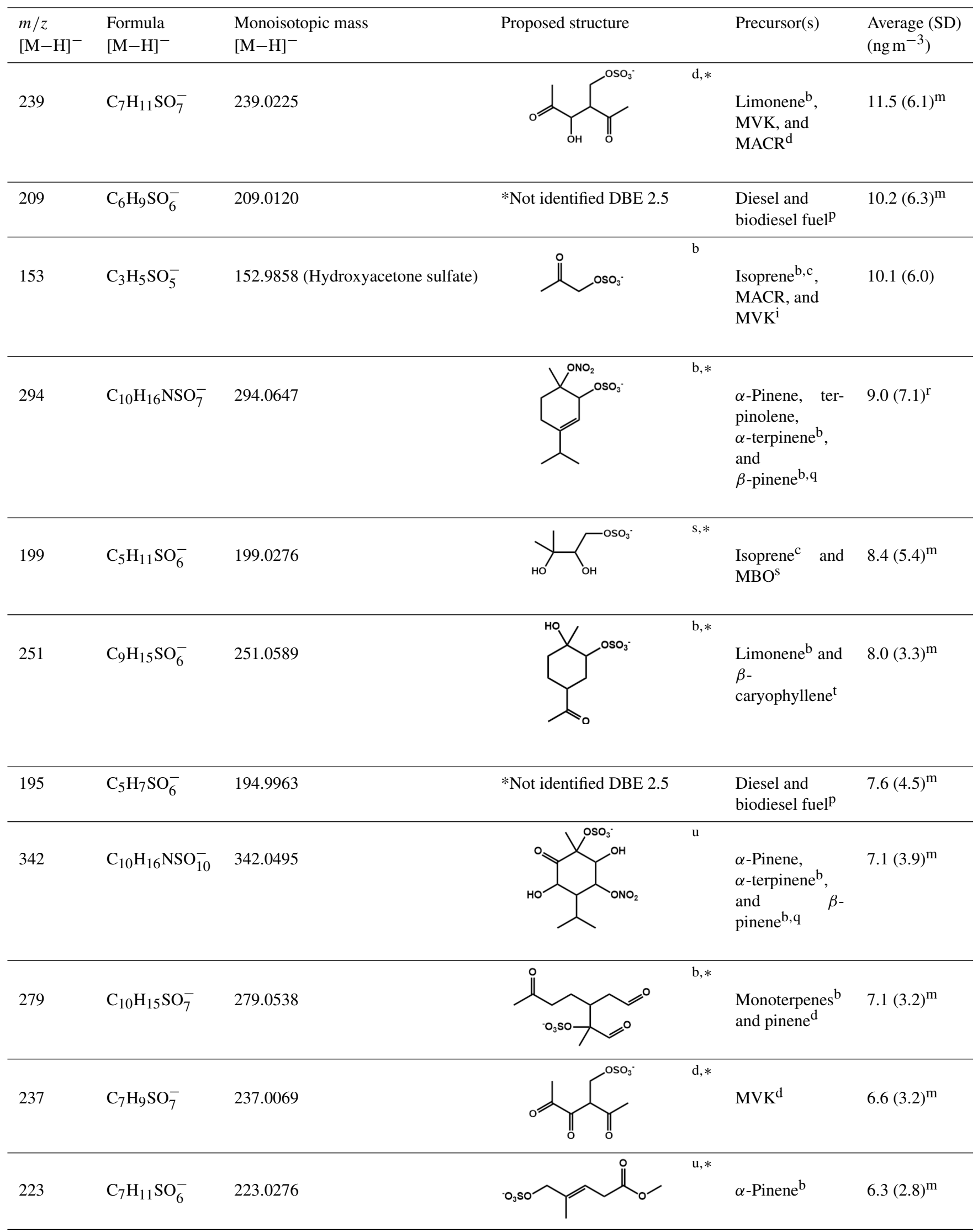


Table 1. Continued.

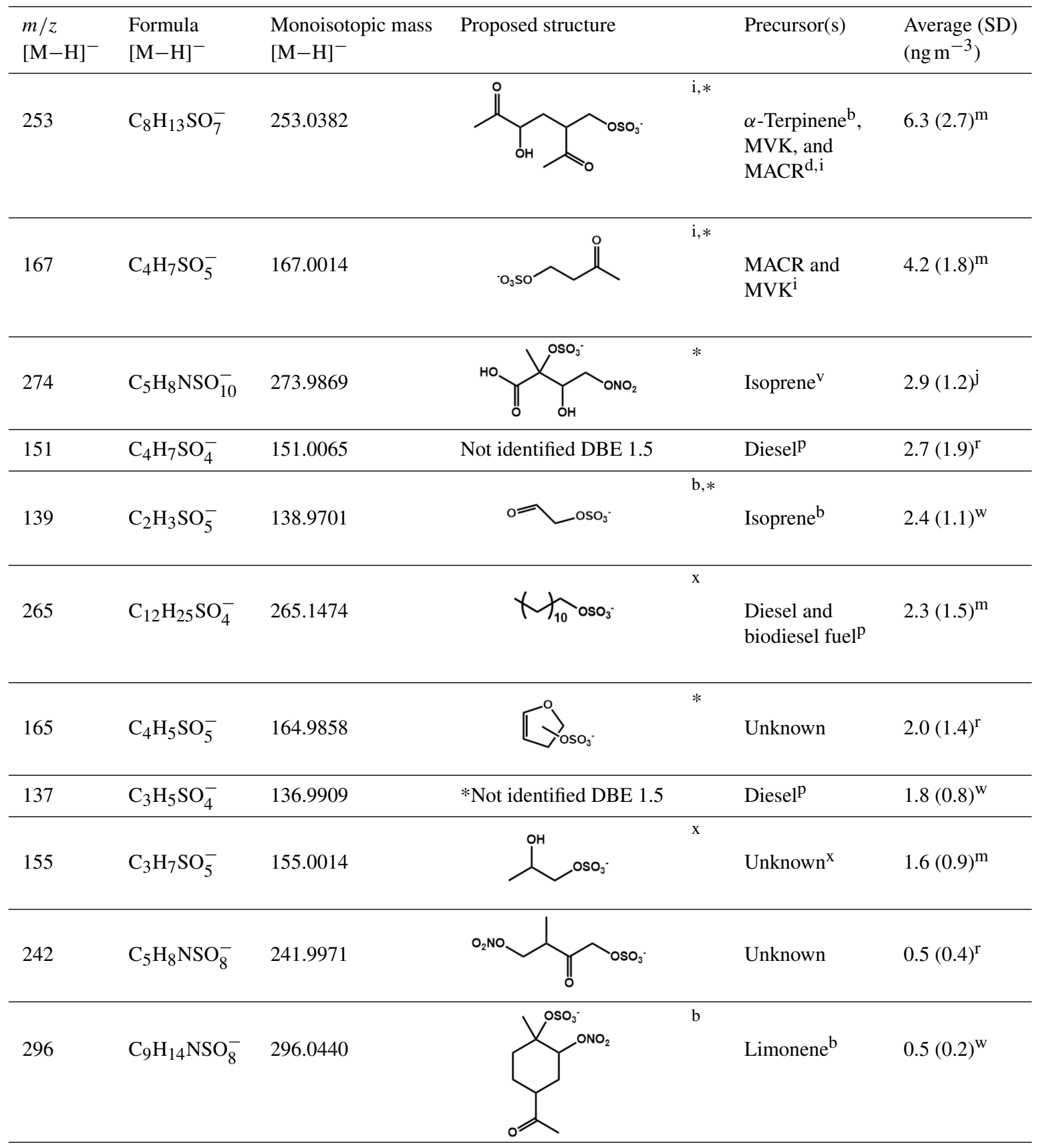

Methyl vinyl ketone (MVK), methacrolein (MACR), 2-methyl-3-buten-2-ol (MBO), double bond equivalence (DBE); ${ }^{a}$ Surratt et al. (2010), ${ }^{\text {b Surratt et }}$ al. (2008), ${ }^{\mathrm{c}}$ Riva et al. (2016b), ${ }^{\mathrm{d}}$ Nozière et al. (2010), ${ }^{\mathrm{e}}$ Gómez-González et al. (2008), ${ }^{\mathrm{f}}$ Hettiyadura et al. (2015), ${ }_{\mathrm{g}}$ quantified using a response factor of $m / z 97$ of the methyltetrol sulfates standard detected in a previous experiment, ${ }^{\mathrm{h}}$ Olson et al. (2011), ${ }^{\mathrm{i}}$ Schindelka et al. (2013), ${ }^{\mathrm{j}}$ quantified against $m / z 97$ of

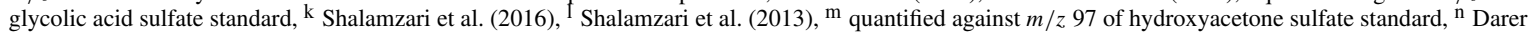
et al. (2011), ${ }^{\circ}$ Riva et al. (2016a), ${ }^{\mathrm{p}}$ Blair et al. (2017), ${ }^{\mathrm{q}}$ Iinuma et al. (2007), ${ }^{\mathrm{r}}$ quantified against $m / z$ 96 of methyl sulfate standard, ${ }^{\mathrm{s}}$ Zhang et al. (2012),

${ }^{\mathrm{t}}$ Chan et al. (2011), ${ }^{\mathrm{u}}$ Yassine et al. (2012), ${ }^{\mathrm{v}}$ Nestorowicz et al. (2018), ${ }^{\mathrm{W}}$ quantified against $m / z 80$ of hydroxyacetone sulfate standard, and ${ }^{\mathrm{x}}$ Hettiyadura et al. (2017).

two following ways: (1) as having a minimum relative intensity in the MS/MS spectra $(\geq 1.0 \%$ for precursors to $m / z 97$, $>12 \%$ for $m / z 96,>5 \%$ for $m / z 81$, and $>3 \%$ for $m / z 80$ in any of the three samples) or (2) by retaining more than 4 min. Despite the observation that organosulfates eluting af- ter 4 min often have higher concentrations than early eluting species, their MS response is observed to be lower because of the increased water content of the mobile phase as water does not desolvate as efficiently as acetonitrile in the ESI source (Hettiyadura et al., 2017). The absolute MS sig- 


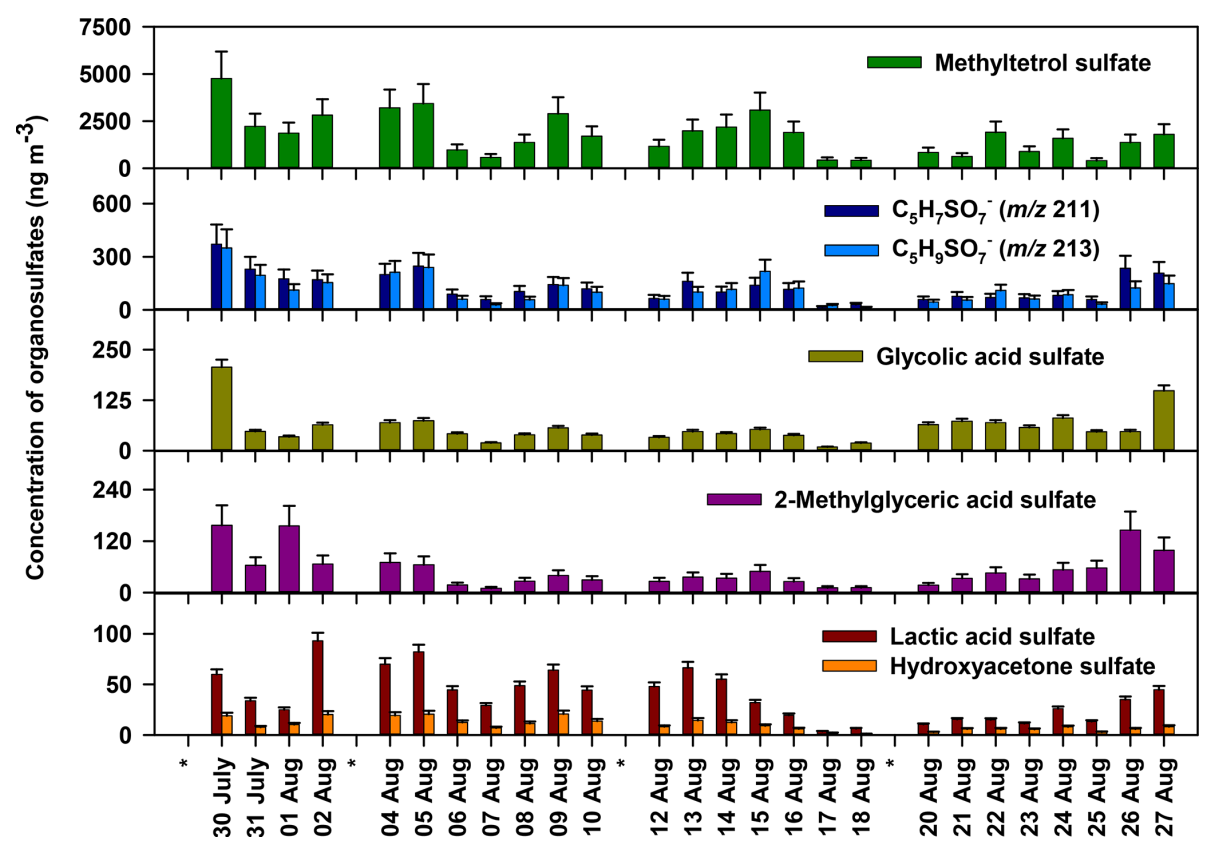

Figure 2. Time series of seven major organosulfate species quantified in August 2015 in Atlanta. Samples that were not analyzed (because they were used for a different purpose) are marked with a star.

nal for precursors to $m / z 97$ was 52,10 , and 8 times greater than MS signals for precursors to $m / z 96,81$, and 80 , respectively; however, due to differing ionization efficiencies and stabilities among these fragment ions, the strength of the MS signal is not indicative of the relative concentrations of species that form these fragments. Table 1 summarizes the major organosulfates' elemental composition, monoisotopic mass, proposed or known structures, and precursor gases. Of the major organosulfates, 26 of the 32 consisted of $\mathrm{C}, \mathrm{H}, \mathrm{O}$, and S, while 6 of 32 consisted of C, H, O, S, and N. Structures were proposed based on elemental composition, double bond equivalence (DBE), retention time, and prior studies.

\subsection{Isoprene-derived organosulfates}

The strongest organosulfate signals observed in $m / z$ 97, 80 , and 81 precursor ion scans are associated with isoprene (Fig. 1, Table 1). Methyltetrol sulfate $(\mathrm{m} / \mathrm{z} 215)$, the most abundant organosulfate observed, is produced from the acid catalyzed nucleophilic addition of sulfate to IEPOX ring (Surratt et al., 2010). Organosulfates with $\mathrm{m} / z 211$ (hydroxymethyl-tetrahydrofuranone sulfates) and 213 (dihydroxymethyl-tetrahydrofuranyl sulfates), of the next-highest abundance, have been observed during the photooxidation of isoprene (Surratt et al., 2008) and are suggested to derive from the oxidation of primary alcohols in methyltetrol sulfates (Hettiyadura et al., 2015). In addition, 14 other major organosulfates identified are known to derive from isoprene and isoprene oxidation products (Table 1). Many of these organosulfates have also been identified as
SOA products from diesel and biodiesel fuel emissions (e.g., 2-methylglyceric acid sulfate, lactic acid sulfate, hydroxyacetone sulfate, $m / z 167,183,197,211,213,237,239$, and 253) (Blair et al., 2017), monoterpenes $(\mathrm{m} / z 239$ and 253) (Surratt et al., 2008), and/or MBO (199; $\mathrm{C}_{5} \mathrm{H}_{11} \mathrm{SO}_{6}^{-}$) (Zhang et al., 2012). However, their moderate to strong correlations with methyltetrol sulfate (Table S1 in the Supplement) and 2methyltetrols (Table S2) suggest that they are mainly derived from isoprene.

Among the major organosulfate signals are those associated with isoprene oxidation under high- $\mathrm{NO}_{x}$ conditions such as 2-methylglyceric acid sulfate, $m / z 260$ and 274. 2-Methylglyceric acid sulfate is a tracer for isoprene high-NO $\mathrm{NO}_{x}$ SOA that is formed by the acid-catalyzed nucleophilic addition of sulfate to methacrylic acid epoxide (MAE) and/or hydroxymethyl-methyl- $\alpha$-lactone (HMML) (Lin et al., 2013). The organosulfate with $m / z 260$ is a nitrooxy organosulfate that derives from the photooxidation of isoprene under high- $\mathrm{NO}_{x}$ conditions (Surratt et al., 2008; Gómez-González et al., 2008). Two isomers of $\mathrm{m} / z 260$ were identified in this study, while up to four isomers of $\mathrm{m} / \mathrm{z} 260$ were reported in Centreville (Surratt et al., 2008). The $m / z 260$ also correlated moderately with methyltetrol sulfate $(r=0.539, p$ value $=0.005$, Table S1), supporting its formation from isoprene. The organosulfate with $\mathrm{m} / z 274$ is also a nitrooxy organosulfate that is derived from isoprene photooxidation under high- $\mathrm{NO}_{x}$ conditions (Nestorowicz et al., 2018). The organosulfate with $m / z 274$ has multiple isomers, whereas only the two isomers retaining greater than $4 \mathrm{~min}$ are considered to be major ones as described 
Table 2. Comparison of organosulfates quantified or semi-quantified in Centreville, AL, from 13 June to 13 July 2013 and in Atlanta, GA, in August 2015. Standard deviations are given in parenthesis.

\begin{tabular}{|c|c|c|c|c|}
\hline \multirow[t]{2}{*}{ Organosulfate } & \multicolumn{2}{|c|}{ Atlanta, GA } & \multicolumn{2}{|c|}{ Centreville, $\mathrm{AL}^{\mathrm{a}}$} \\
\hline & Average $\left(\mathrm{ng} \mathrm{m}^{-3}\right)$ & $\% \mathrm{OC}$ & Average $\left(\mathrm{ng} \mathrm{m}^{-3}\right)$ & $\% \mathrm{OC}$ \\
\hline Hydroxyacetone sulfate $(m / z, 153)^{b}$ & $10.1(6.0)$ & $0.06(0.03)$ & $5.8(3.1)$ & $0.05(0.04)$ \\
\hline Glycolic acid sulfate $(m / z 155)^{b}$ & $58.5(40.2)$ & $0.24(0.14)$ & $20.6(14.3)$ & $0.10(0.08)$ \\
\hline $\mathrm{C}_{3} \mathrm{H}_{7} \mathrm{SO}_{5}^{-}(m / z 155)^{\mathrm{c}}$ & $1.6(0.9)$ & $0.01(0.01)$ & $1.1(0.8)$ & $0.01(0.01)$ \\
\hline Lactic acid sulfate $(m / z 169)^{\mathrm{b}}$ & $38.4(24.2)$ & $0.20(0.11)$ & $16.5(10.3)$ & $0.12(0.10)$ \\
\hline $\mathrm{C}_{4} \mathrm{H}_{7} \mathrm{SO}_{6}^{-}(m / z 183)^{\mathrm{c}}$ & $23.4(14.9)$ & $0.15(0.07)$ & $9.4(5.8)$ & $0.09(0.08)$ \\
\hline $\mathrm{C}_{4} \mathrm{H}_{7} \mathrm{SO}_{7}^{-}(m / z, 199)^{\mathrm{d}}$ & $53.0(42.3)$ & $0.32(0.22)$ & $8.4(9.0)$ & $0.07(0.09)$ \\
\hline $\mathrm{C}_{5} \mathrm{H}_{11} \mathrm{SO}_{6}^{-}(m / z .199)^{\mathrm{c}}$ & $8.4(5.4)$ & $0.06(0.03)$ & $2.6(2.2)$ & $0.03(0.03)$ \\
\hline $\mathrm{C}_{5} \mathrm{H}_{7} \mathrm{SO}_{7}^{-}(m / z 211)^{\mathrm{e}}$ & $131(82)$ & $0.93(0.48)$ & $35.3(25.6)$ & $0.33(0.31)$ \\
\hline $\mathrm{C}_{5} \mathrm{H}_{9} \mathrm{SO}_{7}^{-}(m / z 213)^{\mathrm{e}}$ & $114(79)$ & $0.80(0.48)$ & $31.6(22.5)$ & $0.30(0.26)$ \\
\hline Methyltetrol sulfate $(m / z 215)^{\mathrm{b}}$ & $1792(1085)$ & $12.6(6.3)$ & $668(515)$ & $6.06(5.49)$ \\
\hline $\mathrm{C}_{7} \mathrm{H}_{11} \mathrm{SO}_{7}^{-}(m / z 239)^{\mathrm{c}}$ & $11.5(6.1)$ & $0.10(0.04)$ & $7.0(3.9)$ & $0.09(0.07)$ \\
\hline $\mathrm{C}_{10} \mathrm{H}_{16} \mathrm{NSO}_{10}^{-}(\mathrm{m} / z 342)^{\mathrm{c}}$ & $7.1(3.9)$ & $0.07(0.04)$ & $5.7(5.7)$ & $0.08(0.10)$ \\
\hline Sum & 2249 & 15.5 & 812 & 7.3 \\
\hline
\end{tabular}

in Sect. 3.2 (Fig. 3o). Their longer retention times (5.6 and $5.8 \mathrm{~min}$ ), three additional oxygen atoms, and one unit of unsaturation suggest the presence of a carboxylic acid functional group and a hydroxyl group. Plausible structures for these two organosulfates are diastereomers of 2carboxy-3-hydroxy-4-(nitrooxy)butan-2-yl sulfate (Table 1), which could form by the oxidation of a primary hydroxyl group in 1,3-dihydroxy-2-methyl-4-(nitrooxy)butan-2-yl sulfate (an isomer of $m / z 260, \mathrm{C}_{5} \mathrm{H}_{10} \mathrm{SO}_{9}^{-}$, proposed by Darer et al., 2011) to a carboxylic acid. The strong correlation of these two signals at $m / z 274$ with the less-oxidized isoprene nitrooxy organosulfate $(m / z 260)(r=0.860, p$ value $<0.001$, Table S1) supports this prediction. Overall, these results indicate that isoprene is the major precursor of the most abundant organosulfates in this study.

Isoprene-derived organosulfates explain a significant fraction of isoprene-derived organic aerosol observed in Atlanta that had not previously been identified on a molecular level. By factor analysis of aerosol chemical speciation data (using the multilinear engine - ME-2), IEPOX-derived OA was estimated to account for $29 \%\left(3.3 \mu \mathrm{g} \mathrm{m}^{-3}\right)$ of $\mathrm{PM}_{1} \mathrm{OA}$ at the nearby JST monitoring site in summer 2014, whereas the IEPOX-OA tracers measured in $\mathrm{PM}_{2.5}$ (2-methyltetrols, $\mathrm{C}_{5}$ alkene triols, and 3-methyl-hydrofuran-3,4-diols) accounted for $3 \%$ of $\mathrm{PM}_{1} \mathrm{OA}$ (Rattanavaraha et al., 2017), assuming negligible differences between $\mathrm{PM}_{1}$ and $\mathrm{PM}_{2.5}$. The remaining IEPOX-derived OA corresponded to $10 \%-18 \%$ of $\mathrm{PM}_{1}$ $\mathrm{OC}$ (considering an $\mathrm{OM}$ : OC ratio of $2.05 \pm 0.57)(\mathrm{Xu}$ et al., 2017), and is comparable to the contribution of isoprenederived organosulfates to $\mathrm{PM}_{2.5}$ OC in this study (15.7\%). Additionally, the isoprene-derived organosulfates observed in this study account for more than half of the $\mathrm{PM}_{2.5} \mathrm{sec}$ ondary organic carbon coming from isoprene, which is estimated as $27 \%$ following the SOA tracer method (Al-Naiema et al., 2019; Kleindienst et al., 2007). These results indicate that more than half of the isoprene-derived OA in Atlanta during summer is comprised by organosulfates, mainly methyltetrol sulfate.

\subsection{Monoterpene-derived organosulfates}

Seven of the thirty-two major organosulfates identified in Atlanta (Table 1) were previously detected among the SOA produced from monoterpenes in the presence of $\mathrm{NO}_{x}$ and acidic sulfate seed aerosols (Surratt et al., 2008). Of these, nitrooxy organosulfates at $\mathrm{m} / z$ 342, 294, and 296 are derived from monoterpenes either by photooxidation in the presence of $\mathrm{NO}_{x}$ or from nitrate radical-initiated oxidation (Surratt et al., 2008; Iinuma et al., 2007). The estimated contribution of these seven monoterpene-derived organosulfates is $0.5 \%$ of $\mathrm{PM}_{2.5}$ OC. However, the accuracy of this estimate is limited by the lack of authentic standards for monoterpene organosulfates and the large differences in molecular structure between the monoterpene organosulfates and the standards utilized in this study. The absence of significant correlations among nitrooxy organosulfates with other organosulfates (Table S1) and biogenic SOA tracers that predominantly derive from photooxidation reactions (Table S2) suggest that these nitrooxy organosulfates likely formed by nitrate radical-initiated oxidation. Organosulfates with $m / z \quad 223$, 279 , and 281 have been identified as SOA products of $\alpha$ pinene, as well as from other monoterpenes $(\mathrm{m} / z 279$ and 


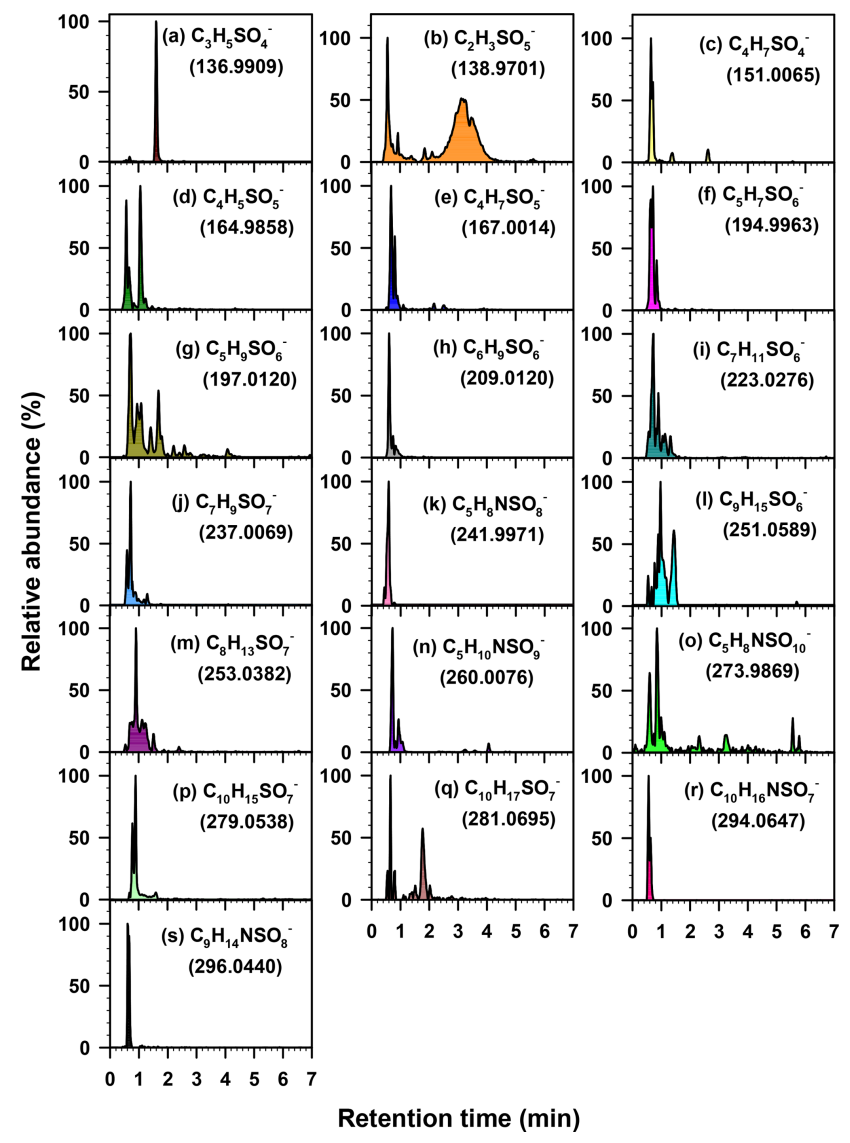

Figure 3. Extracted chromatograms of 19 major organosulfate species obtained from a $\mathrm{PM}_{2.5}$ sample collected in Atlanta using HILIC-ToF. Extracted chromatograms of the remaining 13 major organosulfate species are shown in Hettiyadura et al. (2017) for a $\mathrm{PM}_{2.5}$ sample collected in Centreville. MS data, structures, and VOC precursors of these organosulfates are given in Table 1.

281), in the presence of $\mathrm{NO}_{x}$ and highly acidic sulfate seed aerosol (Surratt et al., 2008). The organosulfate with $m / z 251$ has been identified in SOA from the photooxidation of $\beta$ caryophyllene (a sesquiterpene) and limonene (a monoterpene) in the presence of $\mathrm{NO}_{x}$ and sulfate seed aerosols (Chan et al., 2011; Surratt et al., 2008). These species did not correlate with $\beta$-caryophyllinic acid (Table S2), a SOA tracer for $\beta$-caryophyllene formed under high- $\mathrm{NO}_{x}$ conditions (Jaoui et al., 2007), suggesting that $m / z 251$ mainly forms from monoterpenes. Organosulfates with the same $\mathrm{m} / \mathrm{z}$ were also detected among the organosulfates generated from diesel and biodiesel fuel emissions (Blair et al., 2017) and photooxidation of $n$-alkanes such as decaline $(m / z 281)$ and cyclodecane $(m / z 279$ and 281) (Riva et al., 2016b), but these species are expected to be biogenic in nature due to the dominance of biogenic VOC in Atlanta during summer (Geron et al., 1995; Al-Naiema et al., 2019; Rattanavaraha et al., 2017).

\subsection{Organosulfates derived from anthropogenic sources}

Five organosulfates that were previously reported only in photooxidation of diesel and/or biodiesel fuel in the presence of $\mathrm{SO}_{2}$ were identified among the thirty-two major organosulfates. These include $m / z 137$ and 151 that were generated from diesel fuel emissions and $m / z$ 195, 209, and 265 that were generated from both diesel and biodiesel emissions (Blair et al., 2017). The organosulfate with $\mathrm{m} / z 265$ corresponds to dodecyl sulfate, a widely used surfactant in detergents that can also come from wastewater treatment plants (Hettiyadura et al., 2017). The concentrations of $m / z \quad 209$ and 195 are at least 3 times higher compared with other organosulfates derived from diesel and/or biodiesel emissions in this study (Table 1). These organosulfates $(m / z 209$ and 195) were also detected with a high abundance in urban Shanghai and Los Angeles (Tao et al., 2014). The organosulfates with $m / z, 209$ and 195 are homologs, differing by one methylene. Both compounds have two units of unsaturation and two additional oxygen atoms. Further, their retention times (Fig. 3f and h), which were less than $1 \mathrm{~min}$, suggest that they do not contain a carboxylic acid group, but may contain two carbonyl groups. Additional work is required to determine the position of carbonyl and sulfate groups in these compounds. As $m / z 209$ and 195 are highly abundant in other urban locations and are only known to derive from diesel and/or biodiesel fuel, they may be useful as tracers for SOA derived from diesel and biodiesel emissions.

\subsection{Aromatic organosulfates}

Aromatic sulfur-containing compounds were not detected among the major organosulfate species (Table 1), although some were observed by HILIC-ToF. Two sulfurcontaining compounds had large DBEs indicating aromatic groups: $m / z 185\left(t_{\mathrm{R}} 1.06 \mathrm{~min}, \mathrm{C}_{7} \mathrm{H}_{5} \mathrm{SO}_{4}^{-}\right.$, DBE 5.5, error $3.7 \mathrm{mDa})$ and $201\left(t_{\mathrm{R}} 7.56\right.$ and $8.17 \mathrm{~min}, \mathrm{C}_{7} \mathrm{H}_{5} \mathrm{SO}_{5}^{-}$, DBE 5.5, error $3.5 \mathrm{mDa}$ ). The MS data matched the molecular formula reported by Riva et al. (2015), who detected $\mathrm{m} / \mathrm{z} 185$ in naphthalene and 2-methylnaphthalene photooxidation experiments and identified it as formylbenzenesulfonate by MS fragmentation. Riva et al. (2015) also reported $m / z 201$ in SOA generated by the photooxidation of 2-methylnaphthalene and identified it as 4-sulfobenzoic acid using an authentic standard. In the Atlanta $\mathrm{PM}_{2.5}$, two isomers of $\mathrm{m} / \mathrm{z} 201$, likely conformational isomers of 4sulfobenzoic acid, are observed. The presence of a carboxylic acid group in $m / z 201$ is evident by the retention time > $7 \mathrm{~min}$ in the HILIC method (Hettiyadura et al., 2015). None of the aromatic organosulfates reported in Staudt et al. (2014) (phenyl sulfates and benzyl sulfates) were detected in HILICToF. This may be due to the lower retention times and higher detection limits for aromatic organosulfates in HILIC compared to reversed-phase LC (Hettiyadura et al., 2015). These 
results suggest that aromatic organosulfates have low $\mathrm{PM}_{2.5}$ concentrations in comparison to biogenic organosulfates in Atlanta during the summertime.

\subsection{Additional organosulfates observed in ambient aerosol}

Three organosulfates that have not been previously reported in laboratory smog chamber experiments were detected among the major organosulfate signals: $\mathrm{m} / \mathrm{z} 155$ $\left(\mathrm{C}_{3} \mathrm{H}_{7} \mathrm{SO}_{4}^{-}\right), 165$, and 242 . These signals were previously detected in $\mathrm{PM}_{2.5}$ in Centreville, AL (Hettiyadura et al., 2017), while new insights to their possible precursors and structures are gained here. The species with $m / z 155$ was previously identified as a mono-hydroxy propyl sulfate (Hettiyadura et al., 2017); in Atlanta, it correlated with most of the isoprenederived organosulfates (Table S1), suggesting that it was derived from isoprene.

The organosulfate at $m / z 165$ has an elemental composition of $\mathrm{C}_{4} \mathrm{H}_{5} \mathrm{SO}_{5}^{-}$, indicating the presence of sulfate, an additional oxygenated functional group, and two DBEs. The ToF chromatograms (Fig. 3d) indicate two isomers of $m / z 165$ that eluted in less than $2 \mathrm{~min}$. While both isomers fragmented to $m / z 80$, only the first isomer fragmented into $m / z 96$, which was quantified. Its elemental composition and DBE suggest a dihydrofuran ring structure (Table 1). The strong correlations of $m / z 165$ with methyltetrol sulfate $(r=0.720$, $p$ value $<0.001$; Table $\mathrm{S} 1)$ and 2-methyltetrols $(r=0.670$ and $0.768, p$ value $<0.001$; Table S2) suggest that it is also derived from isoprene.

The organosulfate at $m / z 242$ has an elemental composition of $\mathrm{C}_{5} \mathrm{H}_{8} \mathrm{NSO}_{8}^{-}$, indicating the presence of sulfate, nitrooxy, an additional oxygenated functional group, and two DBEs. Its short retention time of $0.5 \mathrm{~min}$ (Fig. 3k) suggests that it contains a carbonyl group as organosulfates with hydroxyl and carboxylate groups retain more than 1 and 4 min, respectively (Hettiyadura et al., 2015, 2017). A possible formation pathway for this nitrooxy organosulfate can be loss of a water molecule from 2,3-dihydroxy-3-methyl-4(nitrooxy)butyl sulfate (an isomer of $m / z 260, \mathrm{C}_{5} \mathrm{H}_{10} \mathrm{SO}_{9}^{-}$, proposed by Gómez-González et al., 2008) forming an enol that tautomerizes to a carbonyl forming 3-methyl4-(nitrooxy)-2-oxobutyl sulfate (Table 1). Only a few atmospherically relevant isoprene-derived nitrooxy organosulfates have been identified in previous studies. These include $m / z 244,260,274$, and 305 that are derived from isoprene photooxidation under high-NO $\mathrm{NO}_{x}$ conditions (Surratt et al., 2008; Gómez-González et al., 2012). It is expected that $\mathrm{m} / \mathrm{z} 242$ is an additional nitrooxy organosulfate that has not been previously identified in isoprene photooxidation experiments. As $m / z 242$ nitrooxy organosulfate is expected to derive from $m / z 260$, it may provide insight to the atmospheric aging of isoprene-derived SOA, although further evaluation is needed.

\subsection{Comparison of major organosulfates in Atlanta and Centreville}

To better understand the extent to which anthropogenic pollutants influenced biogenic SOA formation in urban Atlanta during August 2015, the concentrations of the major organosulfates were compared to those measured in rural Centreville, AL, during summer 2013 analyzed by similar methodology (Hettiyadura et al., 2017). Although the major organosulfates identified at both sites were similar and mainly derived from isoprene, their concentrations were 2-6 times higher in Atlanta than in Centreville, with the greatest enhancement obtained for 2-methylglyceric acid sulfate (Table 2). As the absolute concentrations of these organosulfates vary with time due to changes in meteorology, which affect isoprene emissions, transport, and mixing of biogenic and anthropogenic pollutants, their relative contributions to $\mathrm{PM}_{2.5}$ OC were compared across the two sites (Table 2). In total, 12 organosulfates quantified or semi-quantified in both studies contributed $7 \%$ of $\mathrm{PM}_{2.5}$ OC in Centreville, and $16 \%$ in Atlanta. These 12 organosulfates accounted for $95 \%$ of the total organosulfate mass in Atlanta and $58 \%-78 \%$ of the total bisulfate ion signal in Centreville (Hettiyadura et al., 2017), indicating that these were the dominant species at both sites. Similarly, the IEPOX-OA in Atlanta during August 2012 ( $31 \%$ of $\left.\mathrm{PM}_{1} \mathrm{OA}\right)$ was $\sim 2$ times greater than IEPOX-OA in Centreville in summer 2013 (18\% of $\mathrm{PM}_{1}$ OA) (Xu et al., 2015a, b). Overall, these results suggest isoprene SOA is 2 times higher in Atlanta compared with Centreville during summer.

Correlations of major organosulfate species were examined at both the Atlanta and Centreville sites to gain insight into their sources and formation pathways. Organosulfates at both sites show moderate to strong correlations with isoprene, isoprene oxidation products, and/or isoprene SOA tracers (Table S2; Table S6 in Hettiyadura et al., 2018), supporting that they mainly derive from isoprene. The correlations of inorganic sulfate with most of the organosulfates were weak or negligible in Atlanta (Table S4), but were moderate to strong in Centreville ( $r=0.5-0.8$ ) (Table S6 in Hettiyadura et al., 2018). This is likely due to the consistently high levels of sulfate observed in urban Atlanta (ranging from 0.82 to $3.24 \mu \mathrm{g} \mathrm{m}^{-3}$ and averaging $1.70 \pm 0.58 \mu \mathrm{g} \mathrm{m}^{-3}$ ) compared with more variable sulfate concentrations in rural Centreville (ranging from 0.42 to $4.17 \mu \mathrm{g} \mathrm{m}^{-3}$ and averaging

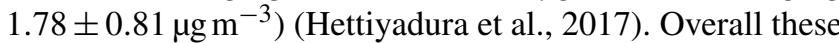
results suggest isoprene and sulfate are important factors influencing the organosulfate formation in both urban Atlanta and rural Centreville.

Isoprene-derived organosulfates indicated a stronger influence of $\mathrm{NO}_{x}$ on their formation in Atlanta compared to Centreville. $\mathrm{NO}_{x}$ influence is evident by the elevated levels of high- $\mathrm{NO}_{x}$ isoprene oxidation products such as 2methylglyceric acid sulfate, which was 6 times higher in Atlanta than in Centreville, and the isoprene-derived ni- 
trooxy organosulfate at $\mathrm{m} / \mathrm{z} 260$ being the eighth strongest organosulfate signal in Atlanta. These results are consistent with the average $\mathrm{NO}_{x}$ concentration in urban Atlanta in August $2015(10.5 \mathrm{ppb})$ that was 15 times greater than the average $\mathrm{NO}_{x}$ concentration in rural Centreville during summer 2013 (0.7 ppb) (SOAS, 2013). Methyltetrol sulfate, the most abundant organosulfate at both sites, is thus expected to derive from low- $\mathrm{NO}_{x}$ oxidation pathway in Centreville as described in Surratt et al. (2010) and by high- $\mathrm{NO}_{x}$ oxidation pathway in Atlanta as described in Jacobs et al. (2014). The moderate and strong correlations obtained for isoprenederived organosulfates with high- $\mathrm{NO}_{x}$ SOA products (Table S3) such as meso-erythritol (Angove et al., 2006) and nitroaromatic compounds (Al-Naiema and Stone, 2017), as well as with ozone (Table S4) that is formed by the photochemical reactions of $\mathrm{NO}_{x}$ and VOC (Blanchard et al., 2014), also support that $\mathrm{NO}_{x}$ plays a key role in isoprene-derived organosulfate formation in Atlanta. However, organosulfate formation from ozonolysis (Riva et al., 2016a) cannot be ruled out. While these findings are consistent with other studies that indicate a substantial influence of anthropogenic $\mathrm{SO}_{2}$ and $\mathrm{NO}_{x}$ on biogenic SOA formation in the southeastern US during summer (Rattanavaraha et al., 2016; Xu et al., 2015a), this study provides evidence for a greater influence of $\mathrm{NO}_{x}$ on isoprene-SOA formation in urban Atlanta, GA, compared to rural Centreville, $\mathrm{AL}$, in summer.

\section{Implications and future work}

This study provides insights to the major organosulfate species that should be targets for future measurements and standard synthesis. The three most abundant organosulfates measured in both Atlanta and Centreville include methyltetrol sulfate, $m / z 211$, and 213. Of these, only a standard for methyltetrol sulfate was previously synthesized (Budisulistiorini et al., 2015; Bondy et al., 2018). Given the ubiquity and high abundance of $m / z 211$ and 213 in the southeastern US and other locations (Hettiyadura et al., 2017; Spolnik et al., 2018), they should be the next highest priorities for authentic standard development. The $\mathrm{m} / z 211$ and 213 also have multiple isomers as described by Hettiyadura et al. (2015) and Spolnik et al. (2018). Further, this study reveals isoprene-derived organosulfates such as 2methylglyceric acid sulfate and $m / z 260$ are useful in distinguishing $\mathrm{SOA}$ formed under high- $\mathrm{NO}_{x}$ conditions in urban environments.

While isoprene was the major precursor to organosulfates at both Atlanta and Centreville, the comparison of these two datasets reveals different anthropogenic influences on biogenic SOA formation (Sect. 3.8). In particular, $\mathrm{NO}_{x}$ had a stronger influence on organosulfate formation in Atlanta, and sulfate had a stronger influence on organosulfate formation in Centreville. Future studies should focus on comparing the major organosulfate species in other urban and rural loca- tions in the southeastern US to determine if these trends are ubiquitous across urban-rural landscapes and to better understand the anthropogenic influences on biogenic SOA formation. While high levels of isoprene-derived organosulfates detected in the southeastern US during summer coincide with high isoprene emissions from plants, high levels of aromatic organosulfates and nitrooxy organosulfates detected in fall and winter coincide with high levels of biomass burning (Ma et al., 2014; He et al., 2014). Thus, longer-term measurements of organosulfates spanning an annual cycle are needed to further evaluate the sources and concentrations of organosulfates in the atmosphere.

Data availability. Organosulfate measurements are given in Table S5. Other $\mathrm{PM}_{2.5}$ measurements such as OC, inorganic sulfate, and SOA measured using GC-MS are provided elsewhere (AlNaiema et al., 2019).

Supplement. The supplement related to this article is available online at: https://doi.org/10.5194/acp-19-3191-2019-supplement.

Author contributions. EAS designed the research and directed the experiments; APSH, IMAN, and DDH analyzed samples; TF collected samples; APSH and EAS interpreted data and wrote the paper; all authors reviewed the paper.

Competing interests. The authors declare that they have no conflict of interest.

Disclaimer. Any opinions, findings, and conclusions or recommendations expressed in this material are those of the author(s) and do not necessarily reflect the views of the National Science Foundation (NSF).

Acknowledgements. The authors would like to thank Emily Geddes, Kaitlin Richards, and Tim Humphry at the Truman State University for synthesizing standards of hydroxyacetone sulfate and glycolic acid sulfate; Sean Staudt at the University of Wisconsin, Madison for synthesizing the lactic acid sulfate standard; Jason D. Surratt, Avram Gold and Zhenfa Zhang at the University of North Carolina at Chapel Hill for providing the methyltetrol sulfate standard; Josh Kettler and Carter Madler for their assistance in sample preparation and analysis; Lynn Teesch and Vic Parcell for their assistance in the University of Iowa High Resolution Mass Spectrometry Facility (HRMSF); and Rodney J. Weber for assistance with sample collection. This research was supported by the National Science Foundation AGS grant number 1405014.

Edited by: Willy Maenhaut

Reviewed by: two anonymous referees 


\section{References}

Al-Naiema, I. M. and Stone, E. A.: Evaluation of anthropogenic secondary organic aerosol tracers from aromatic hydrocarbons, Atmos. Chem. Phys., 17, 2053-2065, https://doi.org/10.5194/acp17-2053-2017, 2017.

Al-Naiema, I. M., Offenberg, J., Lewandowski, M., Fang, T., and Stone, E. A.: Secondary organic aerosols from aromatic hydrocarbons in Atlanta, Georgia, in preparation, 2019.

Angove, D. E., Fookes, C. J. R., Hynes, R. G., Walters, C. K., and Azzi, M.: The characterisation of secondary organic aerosol formed during the photodecomposition of 1,3-butadiene in air containing nitric oxide, Atmos. Environ., 40, 4597-4607, https://doi.org/10.1016/j.atmosenv.2006.03.046, 2006.

Blair, S. L., MacMillan, A. C., Drozd, G. T., Goldstein, A. H., Chu, R. K., Paša-Tolić, L., Shaw, J. B., Tolić, N., Lin, P., Laskin, J., Laskin, A., and Nizkorodov, S. A.: Molecular characterization of organosulfur compounds in biodiesel and diesel fuel secondary organic aerosol, Environ. Sci. Technol., 51, 119-127, https://doi.org/10.1021/acs.est.6b03304, 2017.

Blanchard, C. L., Hidy, G. M., and Tanenbaum, S.: Ozone in the southeastern United States: An observation-based model using measurements from the SEARCH network, Atmos. Environ., 88, 192-200, https://doi.org/10.1016/j.atmosenv.2014.02.006, 2014.

Bondy, A. L., Craig, R. L., Zhang, Z., Gold, A., Surratt, J. D., and Ault, A. P.: Isoprene-derived organosulfates: Vibrational mode analysis by Raman spectroscopy, acidity-dependent spectral modes, and observation in individual atmospheric particles, J. Phys. Chem. A, 122, 303-315, https://doi.org/10.1021/acs.jpca.7b10587, 2018.

Budisulistiorini, S. H., Li, X., Bairai, S. T., Renfro, J., Liu, Y., Liu, Y. J., McKinney, K. A., Martin, S. T., McNeill, V. F., Pye, H. O. T., Nenes, A., Neff, M. E., Stone, E. A., Mueller, S., Knote, C., Shaw, S. L., Zhang, Z., Gold, A., and Surratt, J. D.: Examining the effects of anthropogenic emissions on isoprenederived secondary organic aerosol formation during the 2013 Southern Oxidant and Aerosol Study (SOAS) at the Look Rock, Tennessee ground site, Atmos. Chem. Phys., 15, 8871-8888, https://doi.org/10.5194/acp-15-8871-2015, 2015.

Budisulistiorini, S. H., Baumann, K., Edgerton, E. S., Bairai, S. T., Mueller, S., Shaw, S. L., Knipping, E. M., Gold, A., and Surratt, J. D.: Seasonal characterization of submicron aerosol chemical composition and organic aerosol sources in the southeastern United States: Atlanta, Georgia, and Look Rock, Tennessee, Atmos. Chem. Phys., 16, 5171-5189, https://doi.org/10.5194/acp16-5171-2016, 2016.

Carlton, A. G., Pinder, R. W., Bhave, P. V., and Pouliot, G. A.: To what extent can biogenic SOA be controlled?, Environ. Sci. Technol., 44, 3376-3380, https://doi.org/10.1021/es903506b, 2010.

Chan, M. N., Surratt, J. D., Chan, A. W. H., Schilling, K., Offenberg, J. H., Lewandowski, M., Edney, E. O., Kleindienst, T. E., Jaoui, M., Edgerton, E. S., Tanner, R. L., Shaw, S. L., Zheng, M., Knipping, E. M., and Seinfeld, J. H.: Influence of aerosol acidity on the chemical composition of secondary organic aerosol from $\beta$-caryophyllene, Atmos. Chem. Phys., 11, 1735-1751, https://doi.org/10.5194/acp-11-1735-2011, 2011.

Darer, A. I., Cole-Filipiak, N. C., O'Connor, A. E., and Elrod, M. J.: Formation and stability of atmospherically relevant isoprene- derived organosulfates and organonitrates, Environ. Sci. Technol., 45, 1895-1902, https://doi.org/10.1021/es103797z, 2011.

Gao, S., Surratt, J. D., Knipping, E. M., Edgerton, E. S., Shahgholi, M., and Seinfeld, J. H.: Characterization of polar organic components in fine aerosols in the southeastern United States: Identity, origin, and evolution, J. Geophys. Res.-Atmos., 111, D14314, https://doi.org/10.1029/2005JD006601, 2006.

Geron, C. D., Pierce, T. E., and Guenther, A. B.: Reassessment of biogenic volatile organic compound emissions in the Atlanta area, Atmos. Environ., 29, 1569-1578, https://doi.org/10.1016/1352-2310(94)00274-O, 1995.

Goldstein, A. H., Koven, C. D., Heald, C. L., and Fung, I. Y.: Biogenic carbon and anthropogenic pollutants combine to form a cooling haze over the southeastern United States, P. Natl. Acad. Sci. USA, 106, 8835-8840, https://doi.org/10.1073/pnas.0904128106, 2009.

Gómez-González, Y., Surratt, J. D., Cuyckens, F., Szmigielski, R., Vermeylen, R., Jaoui, M., Lewandowski, M., Offenberg, J. H., Kleindienst, T. E., Edney, E. O., Blockhuys, F., Van Alsenoy, C., Maenhaut, W., and Claeys, M.: Characterization of organosulfates from the photooxidation of isoprene and unsaturated fatty acids in ambient aerosol using liquid chromatography/(-) electrospray ionization mass spectrometry, J. Mass Spectrom., 43, 371-382, https://doi.org/10.1002/jms.1329, 2008.

Gómez-González, Y., Wang, W., Vermeylen, R., Chi, X., Neirynck, J., Janssens, I. A., Maenhaut, W., and Claeys, M.: Chemical characterisation of atmospheric aerosols during a 2007 summer field campaign at Brasschaat, Belgium: sources and source processes of biogenic secondary organic aerosol, Atmos. Chem. Phys., 12, 125-138, https://doi.org/10.5194/acp-12-125-2012, 2012.

Guo, H., Xu, L., Bougiatioti, A., Cerully, K. M., Capps, S. L., Hite Jr., J. R., Carlton, A. G., Lee, S.-H., Bergin, M. H., Ng, N. L., Nenes, A., and Weber, R. J.: Fine-particle water and $\mathrm{pH}$ in the southeastern United States, Atmos. Chem. Phys., 15, 5211-5228, https://doi.org/10.5194/acp-15-5211-2015, 2015.

Hansen, A. M. K., Kristensen, K., Nguyen, Q. T., Zare, A., Cozzi, F., Nøjgaard, J. K., Skov, H., Brandt, J., Christensen, J. H., Ström, J., Tunved, P., Krejci, R., and Glasius, M.: Organosulfates and organic acids in Arctic aerosols: speciation, annual variation and concentration levels, Atmos. Chem. Phys., 14, 7807-7823, https://doi.org/10.5194/acp-14-7807-2014, 2014.

Hansen, D. A., Edgerton, E. S., Hartsell, B. E., Jansen, J. J., Kandasamy, N., Hidy, G. M., and Blanchard, C. L.: The southeastern aerosol research and characterization study: Part 1 - overview, J. Air Waste Manag. Assoc., 53, 1460-1471, https://doi.org/10.1080/10473289.2003.10466318, 2003.

He, Q.-F., Ding, X., Wang, X.-M., Yu, J.-Z., Fu, X.-X., Liu, T.Y., Zhang, Z., Xue, J., Chen, D.-H., Zhong, L.-J., and Donahue, N. M.: Organosulfates from pinene and isoprene over the Pearl River Delta, South China: Seasonal variation and implication in formation mechanisms, Environ. Sci. Technol., 48, 9236-9245, https://doi.org/10.1021/es501299v, 2014.

Hettiyadura, A. P. S., Stone, E. A., Kundu, S., Baker, Z., Geddes, E., Richards, K., and Humphry, T.: Determination of atmospheric organosulfates using HILIC chromatography with MS detection, Atmos. Meas. Tech., 8, 2347-2358, https://doi.org/10.5194/amt8-2347-2015, 2015.

Hettiyadura, A. P. S., Jayarathne, T., Baumann, K., Goldstein, A. H., de Gouw, J. A., Koss, A., Keutsch, F. N., Skog, K., and 
Stone, E. A.: Qualitative and quantitative analysis of atmospheric organosulfates in Centreville, Alabama, Atmos. Chem. Phys., 17, 1343-1359, https://doi.org/10.5194/acp-17-1343-2017, 2017.

Hettiyadura, A. P. S., Xu, L., Jayarathne, T., Skog, K., Guo, H., Weber, R. J., Nenes, A., Keutsch, F. N., Ng, N. L., and Stone, E. A.: Source apportionment of organic carbon in Centreville, AL using organosulfates in organic tracer-based positive matrix factorization, Atmos. Environ., 186, 74-88, https://doi.org/10.1016/j.atmosenv.2018.05.007, 2018.

Hidy, G. M., Blanchard, C. L., Baumann, K., Edgerton, E., Tanenbaum, S., Shaw, S., Knipping, E., Tombach, I., Jansen, J., and Walters, J.: Chemical climatology of the southeastern United States, 1999-2013, Atmos. Chem. Phys., 14, 11893-11914, https://doi.org/10.5194/acp-14-11893-2014, 2014.

Hinkle, D. E., Wiersma, W., and Jurs, S. G.: Applied statistics for the behavioral sciences, Houghton Mifflin Company, College Division, Boston, MA, 2003.

Hu, K. S., Darer, A. I., and Elrod, M. J.: Thermodynamics and kinetics of the hydrolysis of atmospherically relevant organonitrates and organosulfates, Atmos. Chem. Phys., 11, 8307-8320, https://doi.org/10.5194/acp-11-8307-2011, 2011.

Iinuma, Y., Müller, C., Berndt, T., Böge, O., Claeys, M., and Herrmann, H.: Evidence for the existence of organosulfates from $\beta$-pinene ozonolysis in ambient secondary organic aerosol, Environ. Sci. Technol., 41, 6678-6683, https://doi.org/10.1021/es070938t, 2007.

Iinuma, Y., Boge, O., Kahnt, A., and Herrmann, H.: Laboratory chamber studies on the formation of organosulfates from reactive uptake of monoterpene oxides, Phys. Chem. Chem. Phys., 11, 7985-7997, https://doi.org/10.1039/B904025K, 2009.

Jacobs, M. I., Burke, W. J., and Elrod, M. J.: Kinetics of the reactions of isoprene-derived hydroxynitrates: gas phase epoxide formation and solution phase hydrolysis, Atmos. Chem. Phys., 14, 8933-8946, https://doi.org/10.5194/acp-14-8933-2014, 2014.

Jaoui, M., Lewandowski, M., Kleindienst, T. E., Offenberg, J. H., and Edney, E. O.: $\beta$-caryophyllinic acid: An atmospheric tracer for $\beta$-caryophyllene secondary organic aerosol, Geophys. Res. Lett., 34, L05816, https://doi.org/10.1029/2006GL028827, 2007.

Jayarathne, T., Stockwell, C. E., Yokelson, R. J., Nakao, S., and Stone, E. A.: Emissions of fine particle fluoride from biomass burning, Environ. Sci. Technol., 48, 12636-12644, 2014.

Kleindienst, T. E., Jaoui, M., Lewandowski, M., Offenberg, J. H., Lewis, C. W., Bhave, P. V., and Edney, E. O.: Estimates of the contributions of biogenic and anthropogenic hydrocarbons to secondary organic aerosol at a southeastern US location, Atmos. Environ., 41, 8288-8300, https://doi.org/10.1016/j.atmosenv.2007.06.045, 2007.

Kristensen, K. and Glasius, M.: Organosulfates and oxidation products from biogenic hydrocarbons in fine aerosols from a forest in North West Europe during spring, Atmos. Environ., 45, 45464556, https://doi.org/10.1016/j.atmosenv.2011.05.063, 2011.

Lin, P., Yu, J. Z., Engling, G., and Kalberer, M.: Organosulfates in humic-like substance fraction isolated from aerosols at seven locations in east asia: a study by ultra-high-resolution mass spectrometry, Environ. Sci. Technol., 46, 13118-13127, https://doi.org/10.1021/es303570v, 2012.

Lin, Y.-H., Zhang, H., Pye, H. O. T., Zhang, Z., Marth, W. J., Park, S., Arashiro, M., Cui, T., Budisulistiorini, S. H., Sexton, K. G., Vizuete, W., Xie, Y., Luecken, D. J., Piletic, I.
R., Edney, E. O., Bartolotti, L. J., Gold, A., and Surratt, J. D.: Epoxide as a precursor to secondary organic aerosol formation from isoprene photooxidation in the presence of nitrogen oxides, P. Natl. Acad. Sci. USA, 110, 6718-6723, https://doi.org/10.1073/pnas.1221150110, 2013.

Ma, Y., Xu, X., Song, W., Geng, F., and Wang, L.: Seasonal and diurnal variations of particulate organosulfates in urban Shanghai, China, Atmos. Environ., 85, 152-160, https://doi.org/10.1016/j.atmosenv.2013.12.017, 2014.

Nestorowicz, K., Jaoui, M., Rudzinski, K. J., Lewandowski, M., Kleindienst, T. E., Spólnik, G., Danikiewicz, W., and Szmigielski, R.: Chemical composition of isoprene SOA under acidic and non-acidic conditions: effect of relative humidity, Atmos. Chem. Phys., 18, 18101-18121, https://doi.org/10.5194/acp-18-181012018, 2018.

Nozière, B., Ekström, S., Alsberg, T., and Holmström, S.: Radical-initiated formation of organosulfates and surfactants in atmospheric aerosols, Geophys. Res. Lett., 37, L05806, https://doi.org/10.1029/2009GL041683, 2010.

Olson, C. N., Galloway, M. M., Yu, G., Hedman, C. J., Lockett, M. R., Yoon, T., Stone, E. A., Smith, L. M., and Keutsch, F. N.: Hydroxycarboxylic acid-derived organosulfates: Synthesis, stability, and quantification in ambient aerosol, Environ. Sci. Technol., 45, 6468-6474, https://doi.org/10.1021/es201039p, 2011.

Rattanavaraha, W., Chu, K., Budisulistiorini, S. H., Riva, M., Lin, Y.-H., Edgerton, E. S., Baumann, K., Shaw, S. L., Guo, H., King, L., Weber, R. J., Neff, M. E., Stone, E. A., Offenberg, J. H., Zhang, Z., Gold, A., and Surratt, J. D.: Assessing the impact of anthropogenic pollution on isoprene-derived secondary organic aerosol formation in $\mathrm{PM}_{2.5}$ collected from the Birmingham, Alabama, ground site during the 2013 Southern Oxidant and Aerosol Study, Atmos. Chem. Phys., 16, 4897-4914, https://doi.org/10.5194/acp-16-4897-2016, 2016.

Rattanavaraha, W., Canagaratna, M. R., Budisulistiorini, S. H., Croteau, P. L., Baumann, K., Canonaco, F., Prevot, A. S. H., Edgerton, E. S., Zhang, Z., Jayne, J. T., Worsnop, D. R., Gold, A., Shaw, S. L., and Surratt, J. D.: Source apportionment of submicron organic aerosol collected from Atlanta, Georgia, during 2014-2015 using the aerosol chemical speciation monitor (ACSM), Atmos. Environ., 167, 389-402, https://doi.org/10.1016/j.atmosenv.2017.07.055, 2017.

Riva, M., Tomaz, S., Cui, T., Lin, Y.-H., Perraudin, E., Gold, A., Stone, E. A., Villenave, E., and Surratt, J. D.: Evidence for an unrecognized secondary anthropogenic source of organosulfates and sulfonates: Gas-phase oxidation of polycyclic aromatic hydrocarbons in the presence of sulfate aerosol, Environ. Sci. Technol., 49, 6654-6664, https://doi.org/10.1021/acs.est.5b00836, 2015.

Riva, M., Budisulistiorini, S. H., Zhang, Z., Gold, A., and Surratt, J. D.: Chemical characterization of secondary organic aerosol constituents from isoprene ozonolysis in the presence of acidic aerosol, Atmos. Environ., 130, 5-13, https://doi.org/10.1016/j.atmosenv.2015.06.027, 2016a.

Riva, M., Da Silva Barbosa, T., Lin, Y.-H., Stone, E. A., Gold, A., and Surratt, J. D.: Chemical characterization of organosulfates in secondary organic aerosol derived from the photooxidation of alkanes, Atmos. Chem. Phys., 16, 11001-11018, https://doi.org/10.5194/acp-16-11001-2016, $2016 \mathrm{~b}$. 
Schauer, J. J., Mader, B. T., DeMinter, J. T., Heidemann, G., Bae, M. S., Seinfeld, J. H., Flagan, R. C., Cary, R. A., Smith, D., Huebert, B. J., Bertram, T., Howell, S., Kline, J. T., Quinn, P., Bates, T., Turpin, B., Lim, H. J., Yu, J. Z., Yang, H., and Keywood, M. D.: ACE-Asia intercomparison of a thermaloptical method for the determination of particle-phase organic and elemental carbon, Environ. Sci. Technol., 37, 993-1001, https://doi.org/10.1021/es020622f, 2003.

Schindelka, J., Iinuma, Y., Hoffmann, D., and Herrmann, H.: Sulfate radical-initiated formation of isoprene-derived organosulfates in atmospheric aerosols, Faraday Discuss., 165, 237-259, https://doi.org/10.1039/C3FD00042G, 2013.

Shalamzari, M., Ryabtsova, O., Kahnt, A., Vermeylen, R., Hérent, M.-F., Quetin-Leclercq, J., Van der Veken, P., Maenhaut, W., and Claeys, M.: Mass spectrometric characterization of organosulfates related to secondary organic aerosol from isoprene, Rapid Commun. Mass Spectrom., 27, 784-794, https://doi.org/10.1002/rcm.6511, 2013.

Shalamzari, M. S., Kahnt, A., Vermeylen, R., Kleindienst, T. E., Lewandowski, M., Cuyckens, F., Maenhaut, W., and Claeys, M.: Characterization of polar organosulfates in secondary organic aerosol from the green leaf volatile 3-Z-hexenal, Environ. Sci. Technol., 48, 12671-12678, https://doi.org/10.1021/es503226b, 2014.

Shalamzari, M. S., Vermeylen, R., Blockhuys, F., Kleindienst, T. E., Lewandowski, M., Szmigielski, R., Rudzinski, K. J., Spólnik, G., Danikiewicz, W., Maenhaut, W., and Claeys, M.: Characterization of polar organosulfates in secondary organic aerosol from the unsaturated aldehydes 2-E-pentenal, 2-Ehexenal, and 3-Z-hexenal, Atmos. Chem. Phys., 16, 7135-7148, https://doi.org/10.5194/acp-16-7135-2016, 2016.

SOAS Centreville Site Data Download: Tower, S-T20NOxNOyO3, available at: https://esrl.noaa.gov/csd/groups/ csd7/measurements/2013senex/Ground/DataDownload/ (last access: 9 February 2018), 2013.

Spolnik, G., Wach, P., Rudzinski, K. J., Skotak, K., Danikiewicz, W., and Szmigielski, R.: Improved UHPLC-MS/MS methods for analysis of isoprene-derived organosulfates, Anal. Chem., 90, 3416-3423, 2018.

Staudt, S., Kundu, S., Lehmler, H.-J., He, X., Cui, T., Lin, Y.-H., Kristensen, K., Glasius, M., Zhang, X., Weber, R. J., Surratt, J. D., and Stone, E. A.: Aromatic organosulfates in atmospheric aerosols: Synthesis, characterization, and abundance, Atmos. Environ., 94, 366-373, https://doi.org/10.1016/j.atmosenv.2014.05.049, 2014.

Stone, E. A., Yang, L., Yu, L. E., and Rupakheti, M.: Characterization of organosulfates in atmospheric aerosols at Four Asian locations, Atmos. Environ., 47, 323-329, https://doi.org/10.1016/j.atmosenv.2011.10.058, 2012.

Surratt, J. D., Gomez-Gonzalez, Y., Chan, A. W. H., Vermeylen, R., Shahgholi, M., Kleindienst, T. E., Edney, E. O., Offenberg, J. H., Lewandowski, M., Jaoui, M., Maenhaut, W., Claeys, M., Flagan, R. C., and Seinfeld, J. H.: Organosulfate formation in biogenic secondary organic aerosol, J. Phys. Chem. A, 112, 8345-8378, https://doi.org/10.1021/jp802310p, 2008.

Surratt, J. D., Chan, A. W. H., Eddingsaas, N. C., Chan, M., Loza, C. L., Kwan, A. J., Hersey, S. P., Flagan, R. C., Wennberg, P. O., and Seinfeld, J. H.: Reactive intermediates revealed in secondary organic aerosol formation from isoprene, P. Natl. Acad. Sci. USA, 107, 6640-6645, https://doi.org/10.1073/pnas.0911114107, 2010.

Tao, S., Lu, X., Levac, N., Bateman, A. P., Nguyen, T. B., Bones, D. L., Nizkorodov, S. A., Laskin, J., Laskin, A., and Yang, X.: Molecular characterization of organosulfates in organic aerosols from Shanghai and Los Angeles urban areas by nanospray-desorption electrospray ionization high-resolution mass spectrometry, Environ. Sci. Technol., 48, 10993-11001, https://doi.org/10.1021/es5024674, 2014.

Tolocka, M. P. and Turpin, B.: Contribution of organosulfur compounds to organic aerosol mass, Environ. Sci. Technol., 46, 7978-7983, https://doi.org/10.1021/es300651v, 2012.

United States Census Bureau: available at: https://www.census. gov/newsroom/press-releases/2018/popest-metro-county.html, last access: 31 March 2018.

Verma, V., Fang, T., Guo, H., King, L., Bates, J. T., Peltier, R. E., Edgerton, E., Russell, A. G., and Weber, R. J.: Reactive oxygen species associated with water-soluble $\mathrm{PM}_{2.5}$ in the southeastern United States: spatiotemporal trends and source apportionment, Atmos. Chem. Phys., 14, 12915-12930, https://doi.org/10.5194/acp-14-12915-2014, 2014.

Weber, R. J., Sullivan, A. P., Peltier, R. E., Russell, A., Yan, B., Zheng, M., De Gouw, J., Warneke, C., Brock, C., and Holloway, J. S.: A study of secondary organic aerosol formation in the anthropogenic-influenced southeastern United States, J. Geophys. Res.-Atmos., 112, D13302, https://doi.org/10.1029/2007JD008408, 2007.

Wuebbles, D. J. and Jain, A. K.: Concerns about climate change and the role of fossil fuel use, Fuel Process. Technol., 71, 99-119, https://doi.org/10.1016/S0378-3820(01)00139-4, 2001.

Xu, L., Guo, H., Boyd, C. M., Klein, M., Bougiatioti, A., Cerully, K. M., Hite, J. R., Isaacman-VanWertz, G., Kreisberg, N. M., Knote, C., Olson, K., Koss, A., Goldstein, A. H., Hering, S. V., de Gouw, J., Baumann, K., Lee, S.-H., Nenes, A., Weber, R. J., and $\mathrm{Ng}$, N. L.: Effects of anthropogenic emissions on aerosol formation from isoprene and monoterpenes in the southeastern United States, P. Natl. Acad. Sci. USA, 112, 37-42, https://doi.org/10.1073/pnas.1417609112, 2015a.

Xu, L., Suresh, S., Guo, H., Weber, R. J., and Ng, N. L.: Aerosol characterization over the southeastern United States using high-resolution aerosol mass spectrometry: spatial and seasonal variation of aerosol composition and sources with a focus on organic nitrates, Atmos. Chem. Phys., 15, 7307-7336, https://doi.org/10.5194/acp-15-7307-2015, 2015b.

Xu, L., Guo, H., Weber, R. J., and Ng, N. L.: Chemical characterization of water-soluble organic aerosol in contrasting rural and urban environments in the southeastern United States, Environ. Sci. Technol., 51, 78-88, https://doi.org/10.1021/acs.est.6b05002, 2017.

Yassine, M. M., Dabek-Zlotorzynska, E., Harir, M., and SchmittKopplin, P.: Identification of weak and strong organic acids in atmospheric aerosols by capillary electrophoresis/mass spectrometry and ultra-high-resolution Fourier transform ion cyclotron resonance mass spectrometry, Anal. Chem., 84, 6586-6594, https://doi.org/10.1021/ac300798g, 2012.

Zhang, H., Worton, D. R., Lewandowski, M., Ortega, J., Rubitschun, C. L., Park, J.-H., Kristensen, K., Campuzano-Jost, P., Day, D. A., Jimenez, J. L., Jaoui, M., Offenberg, J. H., Kleindienst, T. E., Gilman, J., Kuster, W. C., de Gouw, J., Park, C., 
Schade, G. W., Frossard, A. A., Russell, L., Kaser, L., Jud, W., Hansel, A., Cappellin, L., Karl, T., Glasius, M., Guenther, A., Goldstein, A. H., Seinfeld, J. H., Gold, A., Kamens, R. M., and Surratt, J. D.: Organosulfates as tracers for secondary organic aerosol (SOA) formation from 2-methyl-3-buten-2-ol (MBO) in the atmosphere, Environ. Sci. Technol., 46, 94379446, https://doi.org/10.1021/es301648z, 2012. 